\title{
PENAPISAN ACTINOBACTERIA AKUATIK PENGHASIL ANTIBAKTERI DARI IKAN BANDENG (Chanos chanos) DAN BELANAK (Mugil cephalus) DENGAN METODE DOUBLE-LAYER DIFFUSION
}

\section{Screening of Aquatic Antibacterial-Producing Actinobacteria from Milkfish (Chanos chanos) and Blue-spot Mullet Fish (Mugil cephalus) with Double-Layer Diffusion Method}

\author{
Muhammad Alfid Kurnianto', Harsi Dewantari Kusumaningrum ${ }^{2 *}$, dan Hanifah Nuryani Lioe ${ }^{2}$ \\ ${ }^{1}$ Program Studi Ilmu Pangan, Sekolah Pascasarjana, Institut Pertanian Bogor, Kampus IPB Darmaga, Bogor, Indonesia \\ 2Departemen IImu dan Teknologi Pangan, Fakultas Teknologi Pertanian, Institut Pertanian Bogor, Kampus IPB Darmaga, \\ Bogor, Indonesia \\ *Korespondensi Penulis: h_kusumaningrum@apps.ipb.ac.id
}

Diterima: 14 Januari 2020; Direvisi: 9 April 2020; Disetujui: 2 Juni 2020

\begin{abstract}
ABSTRAK
Saluran pencernaan (terutama usus) ikan perairan estuaria merupakan salah satu ceruk lingkungan potensial Actinobacteria yang belum tereksplorasi. Penelitian ini bertujuan untuk mengisolasi dan mengidentifikasi karakteristik morfologi Actinobacteria asal ikan bandeng (Chanos chanos) dan belanak (Mugil cephalus) serta mengevaluasi aktivitas antimikroba yang dihasilkannya. Penelitian ini diawali dengan mengambil usus ikan, kemudian digesta usus secara perlahan dipisahkan untuk dieksplorasi keberadaan Actinobacteria dengan menggunakan media isolasi selektif. Isolat yang diperoleh dikarakterisasi berdasarkan ciri makroskopik dan mikroskopik, serta dilakukan penapisan antibakteri awal menggunakan metode double-layer diffusion. Isolat dengan zona penghambatan terbaik dipilih untuk dilakukan produksi dan ekstraksi senyawa antibakteri, serta uji aktivitas antibakteri dengan metode difusi cakram terhadap bakteri uji Staphylococcus aureus, Bacillus cereus, Pseudomonas aeruginosa dan Escherichia coli. Sebanyak 44 isolat Actinobacteria telah diisolasi dari digesta usus ikan bandeng (Chanos chanos) dan belanak (Mugil cephalus) menggunakan media strach casein dan actinomycete isolation agar. Sebagian besar isolat yang diperoleh menunjukkan karakteristik morfologi genus Streptomyces sp., seperti koloni memiliki tekstur menyerupai serbuk, bertepung dan kasar, memiliki aerial miselium berwarna putih dan substrat miselium berwarna krim susu, serta memiliki bentuk rantai spora rectus-flexibilis. Proses penapisan antibakteri isolat Actinobacteria menunjukkan 22 isolat memiliki indeks penghambatan terhadap sedikitnya satu bakteri uji, dengan aktivitas terbaik ditunjukkan oleh isolat A-SCA-11. Uji antibakteri terhadap ekstrak kasar isolat A-SCA-11 menunjukkan aktivitas antibakteri berspektrum luas yang mampu menghambat seluruh bakteri uji dengan zona hambat tertinggi pada $P$. aeruginosa.
\end{abstract}

KATA KUNCI : ikan bandeng, ikan belanak, actinobacteria, antimikroba, double-layer diffusion

\begin{abstract}
The gut of estuary fish is one of the potential novel niches of Actinobacteria that has not yet been explored. This study aimed to isolate and identify the morphological characteristics of Actinobacteria from milkfish (Chanos chanos) and blue-spot mullet fish (Mugil cephalus) and to evaluate the antibacterial activity produced. This research was started by taking the fish gut, and then the digesta were slowly separated to explore the presence of Actinobacteria using selective isolation media. The isolates obtained were characterized by macroscopic and microscopic characteristics, and antibacterial preliminary screening of isolates was performed using a double-layer diffusion method. The isolates with the best inhibition zone were selected for production and extraction of antibacterial compounds, and antibacterial activity tests using the disk-diffusion method against the test bacteria Staphylococcus aureus, Bacillus cereus, Pseudomonas aeruginosa, and Escherichia coli. A total of 44 isolates of Actinobacteria have been isolated from the gut of fish using starch casein and actinomycete isolation agar. Most isolates showed morphological characteristics of the genus Streptomyces sp., such as colonies with a tough or powdery texture, antibacterial have white aerial mycelium and milk-cream substrate mycelium, and rectusflexibilis spore chain. The antibacterial preliminary screening of Actinobacteria isolates showed 22 isolates had inhibitory index against at least one test bacterium, with the best activity indicated by A-SCA-11. Antibacterial test of A-SCA-11 crude extract showed broad-spectrum antibacterial activity that was able to inhibit all test bacteria with the highest inhibitory zone on $\underline{P}$ aeruginosa.
\end{abstract}

KEYWORDS: Chanos chanos, Mugil cephalus, actinobacteria, antimicrobial, double-layer diffusion 


\section{PENDAHULUAN}

Actinobacteria merupakan bakteri Gram-positif yang bersifat aerob dan membentuk spora, memiliki kandungan guanin dan sitosin pada genom yang tinggi (55-57\%), memiliki karakteristik koloni yang khas seperti serbuk, bertepung dan kasar, memiliki miselia bercabang sejati yang ditunjukkan pada miselium substrat dan aerial, serta mampu memproduksi pigmen (Anandan, Dharumadurai, \& Manogaran, 2016; Ganesan et al., 2017; Kuncharoen, Fukasawa, Mori, Shiomi, \& Tanasupawat, 2019). Actinobacteria telah dikenal sebagai bakteri penghasil senyawa bioaktif dengan beragam aktivitas biologis (Abdelfattah, Arai, \& Ishibashi, 2016). Sebanyak dua pertiga dari 10.000 senyawa aktif biologis yang berasal dari mikroorganisme diproduksi oleh Actinobacteria (Kumari \& Doss, 2016). Sebagian besar senyawa bioaktif yang dihasilkan merupakan antimikroba, di antaranya tetrasiklin, eritromisin, vancomisin, dan streptomycin (Subramani \& Aalbersberg, 2012; Weber et al., 2015). Selain antimikroba, Actinobacteria juga menghasilkan senyawa bioaktif lainnya seperti antivirus, antiparasit, herbisida, pestisida, antioksidan, antitumor dan enzim (Elbendary et al., 2018; Matsumoto \& Takahashi, 2017).

Actinobacteria memiliki habitat pada ekosistem terestrial dan akuatik (Anandan et al., 2016; Barka et al., 2016). Pada ekosistem akuatik, salah satu ceruk lingkungan potensial yang belum banyak tereksplorasi adalah estuari. Estuari merupakan wilayah perairan tempat bertemunya air laut (asin) dan air sungai (tawar) (Nett, Ikeda, \& Moore, 2009). Pertemuan dua jenis perairan tersebut menyebabkan dinamika ekologis, seperti kondisi salinitas yang unik dan kandungan materi organik yang tinggi (Priya, Anandaraj, \& Ganesan, 2015; Sengupta, Pramanik, Ghosh, \& Bhattacharyya, 2015). Kondisi ini mampu memfasilitasi pertumbuhan berbagai jenis mikroorganisme lebih baik sehingga keanekaragaman mikroorganisme pada ekosistem ini menjadi tinggi. Keanekaragaman yang tinggi menyebabkan terjadinya kompetisi interspesies dalam memperebutkan nutrisi, yang mengakibatkan mikroorganisme berada di bawah tekanan. Kondisi ini mendorong mikroorganisme memproduksi metabolit sekunder sebagai salah satu respon pertahanan mereka (Sengupta et al., 2015).

Selain hidup bebas pada ekosistem akuatik, Actinobacteria juga dapat berasosiasi dengan inang eukariotik pada ekosistem tersebut, salah satunya adalah ikan (Abdelfattah et al., 2016; Jami, Ghanbari, Kneifel, \& Domig, 2015; Lewin et al., 2017). Menurut Bernal, Campa-córdova, Saucedo, \& González (2015), Actinobacteria merupakan bagian dari komunitas mikrobiota unik pada ikan. Penelitian Sahu, Sivakumar, Poorani, Thangaradjou, dan Kannan (2007), menunjukkan kepadatan populasi Actinobacteria tertinggi pada ikan terdapat pada saluran pencernaan (usus). Saluran pencernaan ikan merupakan ceruk unik yang kaya akan nutrisi sehingga mampu mendukung pertumbuhan beragam kelompok mikroorganisme (Datta, Sharma, Kundu, Satya, \& Singh, 2017). Pada saluran pencernaan, Actinobacteria membentuk interaksi yang menguntungkan dengan inang seperti kemampuan mendegradasi pakan sehingga nutrisi menjadi tersedia untuk inang, hingga berperan sebagai mutualis defensive dengan mencegah pertumbuhan bakteri patogen oportunistik pada saluran pencernaan inang (Jami et al., 2015; Lewin et al., 2017; Seipke, Kaltenpoth, \& Hutchings, 2012). Jami et al. (2015) menyebutkan, beberapa genus anggota filum Actinobacteria diketahui berasosiasi dengan ikan seperti Streptomyces, Saccharomonospora, Micromonospora, Arthrobacter, Kocuria, Microbacterium dan Agromyces.

Saat ini, resistensi antimikroba merupakan salah satu ancaman kesehatan paling serius (Mhondoro et al., 2019). Secara global diperkirakan sebanyak 700.000 orang setiap tahunnya meninggal akibat penyakit yang terkait dengan mikroba resisten. Jumlah ini diperkirakan akan terus meningkat mencapai 10 juta kematian pada 2050 dengan kerugian ekonomi mencapai US\$100 triliun (Adeyi, 2016). Tingkat resistensi bakteri terhadap antimikroba yang semakin meningkat juga mengancam kegunaan berbagai jenis antimikroba yang telah dikembangkan, sehingga pengembangan agen antimikroba baru dengan aktivitas yang kuat, berspektrum luas, dan berkelanjutan semakin dibutuhkan (Sathish \& Kokati, 2012; Singh et al., 2016; Ventola, 2015). Singh et al., (2016) menyatakan pencarian dan pengembangan agen antimikroba baru dari sumber alami termasuk mikroba (Actinobacteria) dengan cepat mendapatkan momentum seiring meningkatnya peristiwa resistensi.

Distribusi serta interaksi antara Actinobacteria dengan inang eukariotik (ikan) pada perairan estuari menjadi faktor adaptasi jalur metabolik dan pendorong aktivasi berbagai gen sintesis metabolit sekunder Actinobacteria. Hal ini diharapkan mampu membentuk metabolit sekunder baru dengan aktivitas biologis yang bermanfaat (Hong et al., 2009; Walsh \& Fischbach, 2010).

Penelitian ini bertujuan untuk mendapatkan isolat Actinobacteria akuatik asal ikan bandeng (Chanos chanos) dan belanak (Mugil cephalus) serta mengevaluasi aktivitas antimikroba yang dihasilkan. 


\section{BAHAN DAN METODE}

\section{Bahan}

Bagian ikan yang digunakan adalah usus ikan yang diperoleh dari proses pembedahan ikan bandeng dan belanak segar. Bahan lain yang digunakan antara lain medium actinomycete isolation agar, medium strach casein agar, yeast extract, malt extract, dextrose broth, agar bacto, phospat buffer saline, medium nutrient agar, cycloheximide, nalidixic acid, etil asetat, etanol, medium Mueller Hinton Agar (MHA), amoxicillin dan kultur bakteri uji (Staphylococcus aureus ATCC 25922, Escherichia coli ATCC 25922, Bacillus cereus ATCC 10876 dan Pseudomonas aeruginosa InaCC B52).

\section{Metode}

\section{Pengambilan sampel}

Sebanyak 10 ekor ikan bandeng (Chanos chanos) dengan berat rata-rata $500 \mathrm{~g}$ dan 12 ekor ikan belanak (Mugil cephalus) dengan berat rata-rata $300 \mathrm{~g}$ diperoleh dari tambak tradisional yang berada di sekitar lingkungan estuari di Desa Muara, Kecamatan Suranenggala, Kabupaten Cirebon, Jawa Barat, dan Tempat Pelelangan Ikan (TPI) Bondet, Kecamatan Gunungjati, Kabupaten Cirebon, Jawa Barat. Sebelum dibedah, sampel ikan dimatikan menggunakan anastesi, lalu ditimbang. Pembedahan dimulai dengan mengusap permukaan tubuh ikan dengan etanol $70 \%$ menggunakan kapas steril, lalu rongga tubuh ikan dibuka secara aseptik dan isi perut ikan dikeluarkan. Bagian usus diambil dan dipisahkan, kemudian digesta usus dikeluarkan secara perlahan dan dimasukkan ke dalam microtube yang berisi phosphate buffer saline (PBS) steril. Sampel digesta usus disimpan dalam cooler box berisi ice geluntuk ditransportasikan ke laboratorium. Setelah berada di laboratorium, sampel dihomogenisasi dan disimpan pada suhu $-20^{\circ} \mathrm{C}$ (Jami et al., 2015).

\section{Isolasi dan pemurnian isolat Actinobacteria}

Isolasi dilakukan dengan mengencerkan sebanyak $1 \mathrm{~mL}$ digesta usus ikan ke dalam $9 \mathrm{~mL}$ larutan PBS steril. Proses pengenceran bertingkat dilakukan hingga $10^{-4}$. Larutan campuran sebanyak $0,1 \mathrm{~mL}$ diambil dan diinokulasikan pada cawan berisi media isolasi selektif yaitu Starch Casein Agar (SCA) dan Actinomycete Isolation Agar (AIA) dengan metode spread plate, selanjutnya diinkubasi selama 14 hari pada suhu $30^{\circ} \mathrm{C}$. Koloni Actinobacteria yang tumbuh dimurnikan pada media yeast-malt agar untuk studi lebih lanjut (Jami et al., 2015).

\section{Karakterisasi morfologi}

Karakterisasi morfologi terhadap isolat Actinobacteria murni dilakukan dengan menginokulasikan bakteri ke media ISP-2 (International Streptomyces Project-2) dan diinkubasi selama 7 hari pada suhu $30^{\circ} \mathrm{C}$. Karakteristik morfologi yang terbentuk seperti permukaan koloni, produksi pigmen, rantai spora, serta kehadiran aerial miselium dan substrat miselium diamati (Gebreyohannes, Moges, Sahile, \& Raja, 2013). Aerial miselium dan substrat miselium diklasifikasikan berdasarkan perbedaan warna menurut Bergey manual of systematic bacteriology (Taddei, Rodriguez, MarquezVilchez, \& Castelli, 2006).

\section{Penapisan Actinobacteria penghasil antibakteri}

Penapisan isolat Actinobacteria berdasarkan aktivitas antibakteri dilakukan dengan metode doublelayer agar diffusion (Li, Chen, Jiang, \& Jiang, 2015). Tahapan diawali dengan menyiapkan media nutrient agar (NA) konsentrasi 100\% (28 g medium NA dalam $1000 \mathrm{~mL}$ air destilasi) dan 50\% (28 g medium NA dalam $2000 \mathrm{~mL}$ air destilasi). Sebanyak $15 \mathrm{~mL}$ media NA konsentrasi $100 \%$ dituang terlebih dahulu untuk membentuk lapisan dasar. Setelah memadat, $5 \mathrm{~mL}$ media NA dengan konsentrasi $50 \%$ yang telah diinokulasikan bakteri uji dituang membentuk lapisan atas. Isolat Actinobacteria dengan umur 10 hari dipotong dengan cock borer steril (diameter $6 \mathrm{~mm}$ ) dan diletakkan pada permukaan NA lapisan atas. Selanjutnya cawan diinkubasi selama 24 jam pada suhu $30^{\circ} \mathrm{C}$. Zona hambat yang terbentuk dihitung indeks penghambatannya dengan rumus:

$$
\text { Indeks hambat }=\frac{\begin{array}{c}
\text { diameter zona } \\
\text { bening }(\mathrm{mm})
\end{array}-\begin{array}{c}
\text { diameter zona } \\
\text { koloni }(\mathrm{mm})
\end{array}}{\text { diameter zona koloni }(\mathrm{mm})}
$$

\section{Produksi dan ekstraksi}

Proses produksi ekstrak kasar antibakteri dilakukan dengan metode submerged state fermentation yang memanfaatkan media yeast-malt extract broth sebagai substrat fermentasi. Tahapan pertama yang dilakukan adalah menginokulasikan isolat terpilih ke dalam $100 \mathrm{~mL}$ media produksi yeastmalt extract broth pada erlenmeyer $500 \mathrm{~mL}$ dan diinkubasi pada shaker incubator dengan agitasi 200 rpm selama 10 hari pada suhu $30^{\circ} \mathrm{C}$. Setelah masa inkubasi selesai, media produksi disentrifugasi dengan kecepatan $4000 \mathrm{rpm}$ selama 10 menit pada suhu $4{ }^{\circ} \mathrm{C}$ untuk memisahkan supernatan dari biomassa sel. Supernatan bebas sel diekstraksi dengan pelarut etil asetat ( $p$. a grade) dengan perbandingan 1:1 (v/v). 
Fraksi etil asetat dipisahkan dari supernatan dan diuapkan dengan rotary vacuum evaporator pada suhu $45^{\circ} \mathrm{C}$ hingga didapatkan ekstrak kasar (Zothanpuia et al., 2017).

\section{Uji aktivitas antimikroba}

Uji aktivitas antimikoba ekstrak kasar dilakukan dengan metode difusi cakram. Uji diawali dengan menuangkan medium Mueller Hinton Agar (MHA) steril ke cawan dan ditunggu hingga medium memadat. Medium MHA lalu diusap secara merata dengan swab yang sebelumnya telah dicelupkan kultur bakteri uji dengan kepadatan $1 \times 10^{5}$. Selanjutnya, cakram (diameter $6 \mathrm{~mm}$ ) diteteskan $20 \mu \mathrm{L}$ ekstrak kasar dengan konsentrasi $10 \mathrm{mg} / \mathrm{mL}$, ditempatkan pada permukaan cawan dan diinkubasi selama 24 jam pada suhu $37^{\circ} \mathrm{C}$. Amoxicillin dengan konsentrasi $10 \mu \mathrm{g} /$ $\mathrm{mL}$ digunakan sebagai kontrol positif, sementara DMSO 2\% digunakan sebagai kontrol negatif. Zona hambat yang terbentuk merupakan aktivitas antibakteri dari ekstrak kasar (Mohseni, Norouzi, Hamedi, \& Roohi, 2013).

\section{HASIL DAN PEMBAHASAN}

\section{Isolasi dan Karakterisasi Morfologi Isolat Actinobacteria}

Sebanyak 44 isolat Actinobacteriaberhasil diisolasi dari digesta usus ikan bandeng dan belanak. Dari ke44 isolat yang diperoleh, sebanyak 38 isolat diperoleh dari ikan bandeng, sementara 6 isolat lainnya dari ikan belanak (Tabel 1). Pada penelitian ini, jumlah isolat Actinobacteria yang diisolasi dari ikan bandeng lebih banyak dibandingkan dengan penelitian Sivakumar, Sahu, Manivel, dan Kannan (2006) yang telah mengisolasi sebanyak 20 isolat dari tiga bagian tubuh ikan yang berbeda yaitu insang, kulit permukaan dan usus. Sementara itu pada ikan belanak, jumlah isolat Actinobacteria yang ditemukan jauh lebih sedikit dibandingkan dengan penelitian Murugan, Srinivasan, Sivakumar, Sahu, dan Kannan (2007) yang mengisolasi sebanyak 35 isolat dari digesta usus. Perbedaan hasil ini diduga disebabkan karena adanya perbedaan faktor internal seperti tahap perkembangan dan struktur sistem pencernaan, serta perbedaan faktor eksternal seperti feeding strategy, kondisi perairan, dan tingkat salinitas (Datta et al., 2017). Datta et al. (2017) juga menambahkan bahwa bakteri yang ada pada saluran pencernaan ikan sangat dipengaruhi oleh habitat tempat ikan tinggal dan makanan yang dikonsumsi oleh ikan.

Pada penelitian ini digunakan 2 medium isolasi yang berbeda yaitu SCA dan AIA. Penggunaan medium isolasi yang berbeda bertujuan untuk memperoleh jumlah isolat Actinobacteria yang lebih banyak dan beragam walaupun diisolasi dari sumber yang sama (Hayakawa, Sadakata, Kajiura, dan Nonomura, 1991). Djinni, Defant, Kecha, dan Mancini (2014) menambahkan, pemilihan medium isolasi yang tepat sangat penting untuk meningkatkan presentase pemulihan Actinobacteria . Berdasarkan hasil pada tahap isolasi, mayoritas Actinobacteria yang diperoleh berasal dari medium SCA dibandingkan medium AIA. Hal yang sama dilaporkan oleh Messaoudi, Bendahou, Benamar, dan Abdelwouhid (2015), yang menyatakan bahwa 9 dari 18 isolat Actinobacteria diperoleh dari media SCA. Penelitian lain oleh Mohseni et al. (2013) juga melaporkan bahwa medium SCA menunjukkan pertumbuhan yang lebih baik pada proses isolasi dibandingkan dengan medium ISP-2 dan Kuster agar. Medium SCA mengandung sumber nitrogen seperti kasein dan sumber karbon seperti pati yang mampu menstimulasi pertumbuhan Actinobacteria lebih baik, sehingga dapat memberikan jumlah isolat yang lebih banyak (Messaoudi et al., 2015). Hasani, Kariminik, dan Isaazadeh (2014) juga menyatakan bahwa sumber karbon seperti pati dan sumber nitrogen kompleks seperti casein dan yeast extract merupakan sumber nutrisi terbaik untuk pertumbuhan dan produksi antimikroba oleh Actinobacteria.

Koloni Actinobacteria pada media agar dapat dikenali dan diklasifikasikan melalui pengamatan karakteristik morfologi makroskopik dan mikroskopik. Parameter morfologi tersebut di antaranya seperti tekstur permukaan koloni, keberadaan aerial miselium dan substrat miselium, produksi pigmen, dan tipe penataan spora (Dholakiya, Kumar, Mishra, Mody, \& Jha, 2017). Pada penelitian ini, sebagian besar isolat Actinobacteria yang diperoleh memiliki karakteristik morfologi seperti tekstur permukaan koloni yang kasar, kering, dan berkapur/bertepung, membentuk aerial miselium dan substrat miselium yang mayoritas berwarna putih hingga abu-abu, dapat memproduksi pigmen yang didifusikan pada media pertumbuhan, serta memiliki penataan rantai spora yang sebagian besar bertipe rectus flexibilis (Tabel 1). Beberapa kenampakan keragaman morfologi makroskopik isolat Actinobacteria asal ikan bandeng dan belanak disajikan pada Gambar 1. Berdasarkan karakteristik morfologi tersebut, mayoritas isolat yang didapatkan diduga berasal dari genus Streptomyces. Lewin et al. (2017) menyatakan, genus Streptomyces memiliki sebaran habitat yang paling luas dibandingkan anggota filum Actinobacteria lainnya. Streptomyces memiliki ciri seperti koloni tumbuh lambat, memiliki bau seperti tanah karena menghasilkan metabolit volatil yaitu geosmin, memiliki permukaan koloni yang kasar, bertepung, sedikit menggumpal dan berbentuk 
Tabel 1. Karakteristik morfologi isolat Actinobacteria asal ikan bandeng (Chanos chanos) dan belanak (Mugil cephalus)

Table 1. Morphological characteristics of Actinobacteria from milkfish (Chanos chanos) and blue-spot mullet fish (Mugil cephalus)

\begin{tabular}{|c|c|c|c|c|c|c|}
\hline No & $\begin{array}{l}\text { Isolat/ } \\
\text { Isolates }\end{array}$ & $\begin{array}{c}\text { Permukaan } \\
\text { Koloni/Colony } \\
\text { Surface }\end{array}$ & $\begin{array}{c}\text { Miselium } \\
\text { Aerial/Aerial } \\
\text { mycelium }\end{array}$ & $\begin{array}{c}\text { Miselium } \\
\text { Substrat/Substrate } \\
\text { Mycelium }\end{array}$ & $\begin{array}{l}\text { Pigmen/ } \\
\text { Pigment }\end{array}$ & $\begin{array}{c}\text { Rantai } \\
\text { Spora/Spore } \\
\text { Chain }\end{array}$ \\
\hline & A-SCA-7 & Datar/Flat & Putih/White & Kuning/Yellow & Coklat/Brown & $\mathrm{RF}$ \\
\hline & A-SCA-6 & Timbul/Elevated & Kuning/Yellow & Kuning/Yellow & - & $\mathrm{S}$ \\
\hline & A-SCA-13 & Timbul/Elevated & Putih/White & Krem/Beige & Coklat/Brown & RF \\
\hline & $A-A \mid A-1$ & Timbul/Elevated & Putih/White & Krem/Beige & Kuning/Yellow & $\mathrm{RF}$ \\
\hline & $A-A \mid A-2$ & Datar/Flat & Putih/White & Krem/Beige & Kuning/Yellow & RF \\
\hline & $A-A \mid A-3$ & Timbul/Elevated & Putih/White & Krem/Beige & Kuning/Yellow & $\mathrm{RF}$ \\
\hline & $A-A \mid A-8$ & Timbul/Elevated & Putih/White & Krem/Beige & Kuning/Yellow & $\mathrm{RF}$ \\
\hline 8 & $A-A \mid A-6$ & Timbul/Elevated & Putih/White & Krem/Beige & Kuning/Yellow & RF \\
\hline 9 & $A-A \mid A-4$ & Datar/Flat & Putih/White & Abu-abu/Grey & Coklat/Brown & RF \\
\hline 10 & $A-A \mid A-5$ & Timbul/Elevated & Merah/Red & Violet-Ungu/Violet-Purple & - & $\mathrm{s}$ \\
\hline 11 & A-SCA-4 & Timbul/Elevated & Ungu/Purple & Merah-Ungu/Red-Purple & - & $\mathrm{S}$ \\
\hline 12 & A-SCA-10 & Datar/Flat & Putih/White & Krem/Beige & - & $\mathrm{RF}$ \\
\hline 13 & A-SCA-9 & Datar/Flat & Putih/White & Kuning/Yellow & Coklat/Brown & RF \\
\hline 14 & A-SCA-5 & Timbul/Elevated & Putih/White & Kuning/Yellow & Coklat/Brown & RA \\
\hline 15 & A-SCA-11 & Datar/Flat & Putih/White & Krem/Beige & - & RA \\
\hline 16 & $A-A \mid A-12$ & Datar/Flat & Putih/White & Krem/Beige & - & $\mathrm{RF}$ \\
\hline 17 & A-AIA-13 & Datar/Flat & Putih/White & Putih/White & - & RF \\
\hline 18 & A-SCA-12 & Datar/Flat & Putih/White & Kuning/Yellow & Coklat/Brown & $\mathrm{RF}$ \\
\hline 19 & A-SCA-14 & Datar/Flat & Krem/Beige & Kuning/Yellow & Coklat/Brown & RF \\
\hline 20 & $A-A \mid A-10$ & Timbul/Elevated & Krem/Beige & Kuning/Yellow & - & $\mathrm{RF}$ \\
\hline 21 & A-AIA-9 & Timbul/Elevated & Coklat/Brown & Coklat/Brown & - & RA \\
\hline 22 & A-AIA-14 & Datar/Flat & Putih/White & Kuning/Yellow & Coklat/Brown & RF \\
\hline 23 & $A-A \mid A-11$ & Timbul/Elevated & Putih/White & Coklat/Brown & Coklat/Brown & RF \\
\hline 24 & A-AIA-15 & Datar/Flat & Putih/White & Krem/Beige & - & $\mathrm{s}$ \\
\hline 25 & $A-A \mid A-16$ & Datar/Flat & Abu-abu/Grey & Kuning/Yellow & Coklat/Brown & $\mathrm{RF}$ \\
\hline 26 & A-SCA-8 & Datar/Flat & Abu-abu/Grey & Krem/Beige & Kuning/Yellow & $S$ \\
\hline 27 & A-AIA-17 & Timbul/Elevated & Putih/White & Krem/Beige & - & $S$ \\
\hline 28 & A-SCA-15 & Datar/Flat & Krem/Beige & Krem/Beige & - & $\mathrm{RF}$ \\
\hline 29 & A-SCA-16 & Timbul/Elevated & Putih/White & Putih/White & - & $\mathrm{RF}$ \\
\hline 30 & A-SCA-17 & Timbul/Elevated & Putih/White & Putih/White & - & $\mathrm{RF}$ \\
\hline 31 & A-SCA-18 & Timbul/Elevated & Putih/White & Krem/Beige & - & $\mathrm{RF}$ \\
\hline 32 & A-SCA-19 & Timbul/Elevated & Putih/White & Putih/White & - & RA \\
\hline 33 & A-SCA-20 & Datar/Flat & Putih/White & Krem/Beige & - & $\mathrm{RF}$ \\
\hline 34 & A-AIA-18 & Timbul/Elevated & Oranye/Orange & Oranye/Orange & - & $S$ \\
\hline 35 & A-SCA-21 & Timbul/Elevated & Krem/Beige & Krem/Beige & - & $\mathrm{S}$ \\
\hline 36 & A-SCA-22 & Datar/Flat & Putih/White & Putih/White & - & $\mathrm{RF}$ \\
\hline 37 & A-SCA-23 & Datar/Flat & Putih/White & Putih/White & - & $\mathrm{RF}$ \\
\hline 38 & A-SCA-24 & Datar/Flat & Krem/Beige & Krem/Beige & - & $S$ \\
\hline 39 & E-AIA-26 & Datar/Flat & Putih/White & Krem/Beige & - & RA \\
\hline 40 & E-AIA-30 & Datar/Flat & Putih/White & Putih/White & Coklat/Brown & $\mathrm{RF}$ \\
\hline 41 & E-SCA-31 & Datar/Flat & Kuning/Yellow & Putih/White & Kuning/Yellow & $S$ \\
\hline 42 & E-SCA-32 & Timbul/Elevated & Kuning/Yellow & Kuning/Yellow & - & $\mathrm{S}$ \\
\hline 43 & E-AIA-29 & Datar/Flat & Krem/Beige & Coklat/Brown & - & $S$ \\
\hline 44 & E-AIA-32 & Datar/Flat & Kuning/Yellow & Oranye/Orange & Kuning/Yellow & $\mathrm{RF}$ \\
\hline
\end{tabular}

Keterangan/Notes:

No. 1-38: Isolat dari ikan bandeng (Chanos chanos); No. 39-44: Isolat dari ikan belanak (Mugil cephalus); RA: Relinaculam-Apertum; S: Spira; RF: Rectus-Flexibilis/No. 1-38: Isolates from milkfish (Chanos chanos); No. 39-44: Isolates from blue-spot mullet fish (Mugil cephalus); RA: Relinaculam-Apertum; S: Spira; RF: Rectus-Flexibilis. 

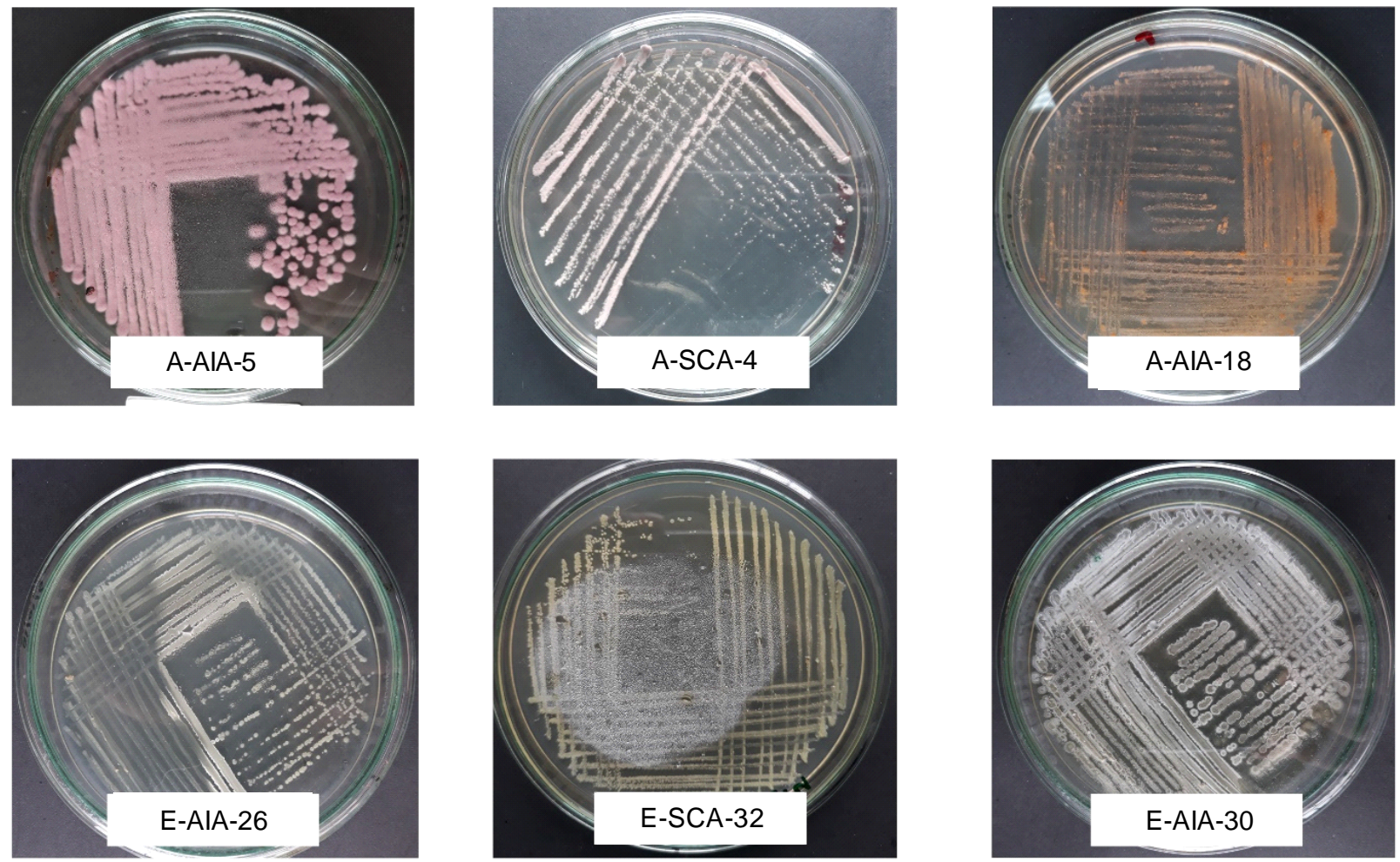

Keterangan/Notes:

A-AIA-5, A-SCA-4 dan A-AIA-18: Isolat dari ikan bandeng (Chanos chanos); E-AIA-26, E-SCA-32 dan E-AIA-30: Isolat dari ikan belanak (Mugil cephallus)/A-AIA-5, A-SCA-4 dan A-AIA-18: isolates from milkfish ( $\underline{\text { Chanos }} \underline{\text { chanos) }}$; EAIA-26, E-SCA-32 dan E-AIA-30: Isolates from blue-spot mullet fish (Mugil cephallus)

Gambar 1. Keragaman morfologi isolat Actinobacteria asal ikan bandeng (Chanos chanos) dan belanak (Mugil cephalus)

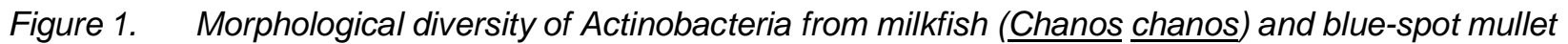
fish (Mugil cephalus)

seperti granular yang merupakan hasil dari pengembangan miselium aerial, membentuk miselium aerial yang memiliki warna putih atau abu-abu, memiliki cincin konsentris yang menunjukkan produksi metabolit sekunder serta menghasilkan berbagai macam pigmen (Gebreyohannes et al., 2013; Hasani et al., 2014). Pigmen yang dihasilkan Streptomyces dapat memberikan warna tertentu pada struktur tertentu dalam sel (endopigmen), dan dapat didifusikan ke luar sel sehingga menyebabkan perubahan warna pada medium pertumbuhannya (eksopigmen) (Azimi, Salehi, \& Bahador, 2017; Ghadin, Zin, \& Sabaratnam, 2008). Karakteristik lain dari Streptomyces adalah memiliki ukuran spora yang sangat kecil (berdiameter kurang dari $1 \mu \mathrm{m}$ ) dan tersusun berdasarkan 3 tipe rantai spora yaitu tipe rantai lurus ke lentur (Rectus-Flexibilis), loop terbuka (Relinaculam-Apertum), dan spiral terbuka atau tertutup (Spira) (Barka et al., 2016)

\section{Potensi Actinobacteria Sebagai Penghasil Antibakteri}

Actinobacteria dikenal sebagai kelompok bakteri yang memproduksi beragam jenis metabolit sekunder. Karuppiah dan Mustaffa (2013) menyatakan bahwa Actinobacteria merupakan filum terbesar dari kingdom bakteri yang telah menghasilkan 10.000 senyawa bioaktif dengan struktur kimia beragam, di mana sekitar 65\%-nya berperan sebagai antimikroba. Beragam senyawa bioaktif yang dihasilkan Actinobacteria menyebabkan diperlukannya proses penapisan untuk menyeleksi isolat penghasil agen antimikroba yang potensial. Menurut Li, Chen, Jiang, dan Jiang, (2015), terdapat dua metode penapisan Actinobacteria yang banyak digunakan yaitu metode cross-streak agar dan metode double-layer diffusion. Dari kedua metode tersebut, metode double-layer diffusion lebih disarankan untuk proses penapisan 
dibandingkan metode cross-streak. Meskipun mudah dan relatif lebih cepat, metode cross-streak memiliki beberapa kelemahan atau kekurangan yang dapat menyebabkan kesalahan positif palsu (false positive) dalam penyimpulan hasil penapisan. Beberapa kelemahan tersebut seperti sulit dalam memperoleh data kuantitatif karena jarak dari zona penghambatan biasanya sangat kabur dan tidak jelas, masalah pengukuran zona hambat akibat tingkat keseragaman goresan yang tidak sama yang menyebabkan perbedaan difusi antibakteri, serta efek mutual antibiosis akibat jarak antar bakteri uji dan penggunaan beberapa kultur sebagai bakteri uji pada cawan yang sama (Velho-Pereira \& Kamat, 2011).

Berdasarkan hasil penapisan menggunakan metode double-layer diffusion (Tabel 2) didapatkan 22 isolat Actinobacteria yang mampu memperlihatkan aktivitas penghambatan terhadap bakteri uji, dengan indeks penghambatan tertinggi ditunjukkan oleh isolat A-AIA-10 yaitu 0,72 pada $S$. aureus. Hasil penapisan juga memperlihatkan hanya satu isolat yaitu isolat $A-$ SCA-11 yang mampu menghambat seluruh bakteri uji (S. aureus, B. cereus, E. coli, dan $P$. aeruginosa). Mayoritas isolat Actinobacteria yang diuji menunjukkan aktivitas penghambatan yang lebih baik terhadap bakteri uji Gram-positif yaitu S. aureus (19 isolat) dan $B$. cereus (9 isolat), dibandingkan dengan bakteri uji Gram-negatif yaitu E. coli (6 isolat) dan $P$. aeruginosa (2 isolat). Hasil yang sama juga ditunjukan oleh Singh et al. (2016), yang melaporkan sebanyak 15 isolat terpilih hasil tahap penapisan menunjukan aktivitas penghambatan yang lebih tinggi terhadap bakteri uji Gram-positif (B. subtilis dan S. aureus). Menurut Singh et al. (2016), perbedaan

Tabel 2. Indeks penghambatan isolat Actinobacteria terhadap bakteri uji

Table 2. Inhibition index of Actinobacteria isolates against targeted bacteria

\begin{tabular}{clcccc}
\hline \multirow{2}{*}{ No } & Isolat/ & \multicolumn{4}{c}{ Indeks Penghambatan/Inhibitory Index } \\
\cline { 3 - 6 } & Isolates & S. aureus & B. cereus & E. coli & P. aeruginosa \\
\hline 1 & A-SCA-7 & - & 0.53 & - & - \\
2 & A-SCA-6 & 0.48 & - & - & - \\
3 & A-SCA-13 & 0.59 & - & - & - \\
4 & A-SCA-10 & 0.67 & - & - & - \\
5 & A-SCA-9 & 0.71 & - & - & - \\
6 & A-SCA-5 & 0.69 & 0.45 & 0.56 & - \\
7 & A-SCA-11 & 0.71 & 0.39 & 0.60 & 0.42 \\
8 & A-AIA-12 & 0.63 & - & - & - \\
9 & A-AIA-13 & 0.56 & 0.37 & - & - \\
10 & A-SCA-12 & 0.44 & - & - & - \\
11 & A-AIA-10 & 0.72 & 0.58 & 0.55 & - \\
12 & A-AIA-9 & 0.54 & - & - & - \\
13 & A-AIA-16 & 0.58 & - & - & - \\
14 & A-SCA-8 & 0.68 & 0.51 & 0.63 & - \\
15 & A-AIA-17 & 0.68 & - & 0.31 & - \\
16 & A-SCA-18 & 0.39 & - & - & - \\
17 & A-SCA-19 & 0.55 & - & - & - \\
18 & A-SCA-22 & 0.55 & 0.36 & - & - \\
19 & E-AIA-26 & 0.44 & - & 0.37 & - \\
20 & E-SCA-31 & - & - & - & 0.30 \\
21 & E-SCA-32 & 0.39 & 0.56 & - & - \\
22 & E-AIA-32 & - & 0.44 & - & - \\
\hline
\end{tabular}

Keterangan/Notes :

No.1-18: Isolat dari ikan bandeng (Chanos chanos); No 19-22: Isolat dari ikan belanak (Mugil cephalus); (-): tidak ada penghambatan/ No. 1-18: Isolates from milkfish (hanos chanos); No. 19-22: Isolates from blue-spot mullet fish (Mugil cephalus); (-): no inhibition zone 
penghambatan ini terkait dengan keberadaan lapisan lipopolisakarida (LPS) yang merupakan unit struktural utama dari dinding sel kelompok bakteri Gram-negatif. LPS memiliki sifat hidrofobik sehingga membuat dinding sel bakteri Gram-negatif menjadi impermeabel terhadap zat terlarut lipofilik (Kim, Na, \& Jeon, 1994). Selain itu, perbedaan aktivitas penghambatan juga dapat disebabkan oleh perbedaan kemampuan biosintesis senyawa antimikroba tiap isolat, di mana hal ini dipengaruhi oleh faktor internal seperti kapasitas metabolisme dari mikroorganisme penghasil dan faktor eksternal seperti nutrisi dan kondisi lingkungan (Anandan et al., 2016). Berdasarkan hasil penapisan, isolat A-SCA-11 dipilih sebagai isolat terbaik karena mampu menunjukkan aktivitas penghambatan terhadap seluruh bakteri uji.

\section{Aktivitas Antimikroba Isolat Terpilih}

Isolat Actinobacteria terpilih yaitu A-SCA-11 dikulturkan kembali pada medium produksi yeast-malt extract broth, diinkubasi dan diekstraksi dengan pelarut organik etil asetat untuk mendapatkan ekstrak kasar antibakteri. Uji aktivitas antibakteri dengan menggunakan metode difusi cakram menunjukkan ekstrak kasar isolat A-SCA-11 memiliki aktivitas antibakteri berspektrum luas (broad-spectrum) yang mampu menghambat seluruh bakteri uji dengan zona hambat yang berbeda-beda. Hasil serupa dilaporkan Messaoudi et al., (2015) yang menyatakan bahwa ekstrak kasar Actinobacteria memiliki spektrum penghambatan yang luas terhadap $S$. aureus, $B$. cereus, $B$. subtilis, $K$. pneumonia dan $B$. strearothermophilus. Perbedaan zona hambat tersebut diduga disebabkan karena perbedaan struktur dinding sel pada masing-masing bakteri uji. Sperandio, Huang, \& Hamblin (2013) menjelaskan, bahwa bakteri Grampositif memiliki lapisan dinding sel yang tebal dan berpori dengan komponen utama peptidoglikan yang saling terhubung mengelilingi membran sitoplasma, sementara itu bakteri Gram-negatif memiliki lapisan peptidoglikan yang lebih tipis, namun terdapat lapisan pelindung tambahan berupa lipid yang disebut outer membrane (OM). Sharma, Chiang, dan Hamblin (2011) menambahkan, bakteri Gram-positif memiliki lapisan peptidoglikan berpori dan bilayer lipid tunggal, sedangkan bakteri Gram-negatif memiliki lapisan bilayer ganda yang mengapit lapisan peptidoglikan ditambah lapisan OM lipopolisakarida sehingga menghasilkan tingkat permeabilitas yang rendah untuk molekul kecil lipofilik.

Uji aktivitas antibakteri juga menunjukkan zona hambat tertinggi diperoleh pada bakteri uji Gramnegatif $P$. aeruginosa sebesar $15,34 \mathrm{~mm}$ dan terendah pada bakteri uji Gram-positif $B$. cereus sebesar 11,60 $\mathrm{mm}$ (Tabel 3). Aktivitas antibakteri yang tinggi pada bakteri uji Gram-negatif diduga disebabkan karena senyawa aktif yang terkandung dalam ekstrak kasar mampu melakukan pengikatan langsung dengan fosfolipid sehingga jalur transportasi fosfolipid (phospholipid transportation pathway) antara kedua membran menjadi terputus. Hal ini mengakibatkan terjadinya disregulasi komposisi membran dan mengganggu integritas membran (Umerska et al., 2018). Selain mekanisme tersebut, senyawa aktif yang terkandung dalam ekstrak kasar juga diduga memiliki berat molekul kurang dari $600 \mathrm{Da}$. Menurut Choi \& Lee (2019), senyawa dengan berat molekul lebih dari 600 Da tidak dapat melewati lapisan OM, sedangkan senyawa dengan berat molekul kurang dari $600 \mathrm{Da}$ dapat melewati lapisan OM melalui saluran khusus yang disebut porin. Porin merupakan outer membrane protein (OMPs) pada lapisan OM yang memungkinkan molekul kecil seperti asam amino dan sakarida kecil lewat (Breijyeh, Jubeh, \& Karaman, 2020). Sementara

Tabel 3. Zona penghambatan $(\mathrm{mm})$ dari ekstrak kasar antimikroba Actinobacteria $(10 \mathrm{mg} / \mathrm{mL})$ menggunakan metode difusi cakram

Table 3. Inhibition zone ( $\mathrm{mm}$ ) of antibacterial crude extract of Actinobacteria (10 $\mathrm{mg} / \mathrm{mL}$ ) by disk diffusion method

\begin{tabular}{lcccc}
\hline Ekstrak Kasar/ & \multicolumn{4}{c}{ Zona Hambat/Inhibitory Zone (mm) } \\
\cline { 2 - 5 } Crude Extracts & S. aureus & B. cereus & E. coli & P. aeruginosa \\
\hline A-SCA-11 & $13.30 \pm 1.33$ & $11.60 \pm 1.36$ & $11.72 \pm 1.46$ & $15.34 \pm 1.65$ \\
Kontrol (+) & $31.80 \pm 0.12$ & $22.90 \pm 0.05$ & $27.10 \pm 0.21$ & $29.20 \pm 0.09$ \\
Kontrol (-) & $0.00 \pm 0.00$ & $0.00 \pm 0.00$ & $0.00 \pm 0.00$ & $0.00 \pm 0.00$ \\
\hline
\end{tabular}

Keterangan/Notes :

Keterangan : A-SCA-11: Isolat dari ikan bandeng (Chanos chanos); Nilai rata-rata \pm Standar Deviasi dari 3 ulangan;

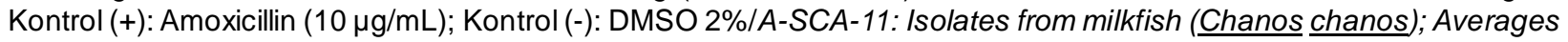
value \pm Standart Deviation from three replication; Control (+): Amoxicillin (10 $\mu \mathrm{g} / \mathrm{mL})$; Control (-): DMSO $2 \%$ 
itu, aktivitas antibakteri yang rendah pada $B$. cereus diduga karena kemampuannya menghasilkan enzim $\beta$-laktamase kuat yang memberikan resistensi terhadap jenis antibiotik $\beta$-laktam dan kemampuannya membentuk spora (Bottone, 2010; Owusu-Kwarteng, Wuni, Akabanda, Tano-Debrah, \& Jespersen, 2017). Louie et al. (2012) menyatakan bahwa spora yang dibentuk oleh Bacillus sp. tidak dapat dihancurkan dengan antibiotik. Meskipun terdapat beberapa dugaan mekanisme aktivitas antibakteri yang ditunjukkan oleh ekstrak kasar A-SCA-11 terhadap bakteri Gram-positif atau negatif, harus dilakukan proses pemurnian untuk mengetahui karakteristik senyawa antibakteri yang dihasilkan dan analisis mode aksi terhadap bakteri uji untuk membuktikan dugaan-dugaan tersebut. Berdasarkan uji aktivitas antibakteri, ekstrak kasar A-SCA-11 dengan konsentrasi $10 \mathrm{mg} / \mathrm{mL}$ mampu menunjukkan aktivitas yang cukup baik dan potensial untuk dilakukan pengembangan selanjutnya. Namun, aktivitas tersebut masih lebih rendah dibandingkan dengan kontrol positif (amoxicillin). Rendahnya aktivitas tersebut diduga disebabkan karena senyawa antibakteri yang belum murni sehingga menyebabkan aktivitas spesifik sebenarnya belum terlihat. Jozala et al.(2008) menyatakan bahwa senyawa pengotor dapat membentuk agregat yang dapat mengurangi aktivitas spesifik antibakterinya. Zhang et al.(2009) menambahkan bahwa terjadi peningkatan aktivitas spesifik sebanyak 1.381,9 kali lipat dari senyawa antibakteri pentocin 31-1 murni dengan perbedaan mencapai 76,8\% dari aktivitas ekstrak kasar.

\section{KESIMPULAN}

Sebanyak 44 isolat Actinobacteria asal ikan bandeng (Chanos chanos) dan belanak (Mugil cephalus) telah diisolasi dari medium SCA dan AIA. Sebagian besar isolat memperlihatkan karakteristik morfologi genus Streptomyces spp. Hasil penapisan dengan metode double-layer diffusion menunjukkan sebanyak 22 isolat memiliki aktivitas penghambatan terhadap sedikitnya satu bakteri uji, dengan aktivitas terbaik ditunjukan oleh isolat A-SCA-11. Uji aktivitas antibakteri ekstrak kasar isolat terbaik yaitu A-SCA11 menunjukkan aktivitas antibakteri berspekrum luas yang mampu menghambat seluruh bakteri uji, dengan zona hambatan tertinggi diperoleh pada $P$. aeruginosa sebesar $15,34 \mathrm{~mm}$. Hasil tersebut menunjukkan isolat A-SCA-11 sebagai kandidat bakteri penghasil antibakteri yang potensial.

\section{UCAPAN TERIMA KASIH}

Terimakasih kepada Kementerian Riset, Teknologi dan Pendidikan Tinggi Republik Indonesia melalui pendanaan penelitian melalui Beasiswa Program
Magister Menuju Doktor Untuk Sarjana Unggul (PMDSU) berdasarkan kontrak No. 4418 / IT3.11 / PN / 2018.

\section{DAFTAR PUSTAKA}

Abdelfattah, M. S., Arai, M. A., \& Ishibashi, M. (2016). Bioactive secondary metabolites with unique aromatic and heterocyclic structures obtained from terrestrial actinomycetes species. Chemical and Pharmaceutical Bulletin, 64(7), 668-675. https:// doi.org/10.1248/cpb.c16-00038

Adeyi, O. O. (2016). Drug-Resistant Infections: A Threat to Our Economic Future. World Bank Report (Vol. 2). https://doi.org/10.1007/s11947-009-0181-3

Anandan, R., Dharumadurai, D., \& Manogaran, G. P. (2016). An Intriduction to Actinobacteria. In D. Dharumadurai (Ed.), Actinobacteria - Basics and Biotechnological Applications (Vol. I, p. 388). InterchOpen. https://doi.org/10.1016/ j.colsurfa.2011.12.014

Azimi, S., Salehi, M. B., \& Bahador, N. (2017). Isolation and Identification of Streptomyces ramulosus from Soil and Determination of Antimicrobial Property of its Pigment. Modern Medical Laboratory Journal, 1(1), 36-41.

Barka, E. A., Vatsa, P., Sanchez, L., Gaveau-vaillant, N., Jacquard, C., Klenk, H., ... Wezel, P. Van. (2016). Taxonomy, Physiology, and Natural Products of Actinobacteria, 80(1), 1-43. https://doi.org/10.1128/ MMBR.00019-15.Address

Bernal, M. G., Campa-córdova, Á. I., Saucedo, P. E., \& González, M. C. (2015). Isolation and in vitro selection of actinomycetes strains as potential probiotics for aquaculture. Veterinary World, 8, 170-176. https:// doi.org/10.14202/vetworld.2015.170-176.

Bottone, E. J. (2010). Bacillus cereus, a volatile human pathogen. Clinical Microbiology Reviews, 23(2), 382398. https://doi.org/10.1128/CMR.00073-09

Breijyeh, Z., Jubeh, B., \& Karaman, R. (2020). Resistance of gram-negative bacteria to current antibacterial agents and approaches to resolve it. Molecules, 25(6). https://doi.org/10.3390/molecules25061340

Choi, U., \& Lee, C. R. (2019). Antimicrobial agents that inhibit the outer membrane assembly machines of gram-negative bacteria. Journal of Microbiology and Biotechnology, 29(1), 1-10. https://doi.org/10.4014/ jmb.1804.03051

Datta, A. A., Sharma, A. K., Kundu, R., Satya, \&, \& Singh, P. (2017). Diversity and enzymatic profile of bacterial flora in the gut of an estuarine fish, Mugil jerdoni. Indian Journal of Geo Marine Sciences, 46(06), 1116-1127.

Dholakiya, R. N., Kumar, R., Mishra, A., Mody, K. H., \& Jha, B. (2017). Antibacterial and antioxidant activities of novel actinobacteria strain isolated from Gulf of Khambhat, Gujarat. Frontiers in Microbiology, 8(DEC),1-16.https:/ /doi.org/10.3389/fmicb.2017.02420

Djinni, I., Defant, A., Kecha, M., \& Mancini, I. (2014). Metabolite profile of marine-derived endophytic Streptomyces sundarbansensis WR1L1S8 by liquid chromatography-mass spectrometry and evaluation 
of culture conditions on antibacterial activity and mycelial growth. Journal of Applied Microbiology, 116(1), 39-50. https://doi.org/10.1111/jam.12360

Elbendary, A. A., Hessain, A. M., El-Hariri, M. D., Seida, A. A., Moussa, I. M., Mubarak, A. S., ... El Jakee, J. K. (2018). Isolation of antimicrobial producing Actinobacteria from soil samples. Saudi Journal of Biological Sciences, 25(1), 44-46. https://doi.org/ 10.1016/j.sjbs.2017.05.003

Ganesan, P., Reegan, A. D., David, R. H. A., Gandhi, M. R., Paulraj, M. G., Al-Dhabi, N. A., \& Ignacimuthu, S. (2017). Antimicrobial activity of some actinomycetes from Western Ghats of Tamil Nadu, India. Alexandria Journal of Medicine, 53(2), 101-110. https://doi.org/ 10.1016/j.ajme.2016.03.004

Gebreyohannes, G., Moges, F., Sahile, S., \& Raja, N. (2013). Isolation and characterization of potential antibiotic producing actinomycetes from water and sediments of Lake Tana, Ethiopia. Asian Pacific Journal of Tropical Biomedicine, 3(6), 426-435. https:/ /doi.org/10.1016/S2221-1691(13)60092-1

Ghadin, N., Zin, N. M., \& Sabaratnam. (2008). Isolation and Characterization of Novel Endophytic Streptomyces SUK 06 with Antimicrobial Activity from Malaysian Plant. Asian Journal of Plant Science, 7(2), 189-193.

Hasani, A., Kariminik, A., \& Isaazadeh, K. (2014). Streptomycetes/: Characteristics and Their Antimicrobial Activities. International Journal of Advanced Biological and Biomedical Research, 2(1), 63-75.

Hayakawa, M., Sadakata, T., Kajiura, T., \& Nonomura, H. (1991). New methods for the highly selective isolation of Micromonospora and Microbispora from soil. Journal of Fermentation and Bioengineering, 72(5), 320326.https://doi.org/10.1016/0922-338X(91)90080-Z

Hong, K., Gao, A. H., Xie, Q. Y., Gao, H., Zhuang, L., Lin, H. P., ... Ruan, J. S. (2009). Actinomycetes for marine drug discovery isolated from mangrove soils and plants in China. Marine Drugs. https://doi.org/ 10.3390/md7010024

Jami, M., Ghanbari, M., Kneifel, W., \& Domig, K. J. (2015). Phylogenetic diversity and biological activity of culturable Actinobacteria isolated from freshwater fish gut microbiota. Microbiological Research. https:// doi.org/10.1016/j.micres.2015.01.009

Jozala, A. F., Lopes, A. M., Mazzola, P. G., Magalhães, P. O., Vessoni Penna, T. C., \& Pessoa, A. (2008). Liquidliquid extraction of commercial and biosynthesized nisin by aqueous two-phase micellar systems. Enzyme and Microbial Technology, 42(2), 107-112. https://doi.org/10.1016/j.enzmictec.2007.08.005

Karuppiah, P., \& Mustaffa, M. (2013). Antibacterial and antioxidant activities of Musa sp. leaf extracts against multidrug resistant clinical pathogens causing nosocomial infection. Asian Pacific Journal of Tropical Biomedicine, 3(9), 737-742. https://doi.org/10.1016/ S2221-1691(13)60148-3

Kim, K. J., Na, Y. E., \& Jeon, K. W. (1994). Bacterial endosymbiont-derived lipopolysaccharides and a protein on symbiosome membranes in newly infected amoebae and their roles in lysosome- symbiosome fusion. Infection and Immunity, 62(1), 65-71. https:// doi.org/10.1016/0169-4758(94)90005-1
Kumari, P. R. T., \& Doss, A. (2016). Purification and Antibacterial Activity of Marine Actinomycetes against Human and Fish Pathogens. Journal of Marine Science: Research \& Development, 06(06), 4-7. https://doi.org/10.4172/2155-9910.1000215

Kuncharoen, N., Fukasawa, W., Mori, M., Shiomi, K., \& Tanasupawat, S. (2019). Diversity and Antimicrobial Activity of Endophytic Actinomycetes Isolated from Plant Roots in Thailand. Microbiology (Russian Federation), 88(4), 479-488. https://doi.org/10.1134/ S0026261719040088

Lewin, G., Carlon, C., Chevrette, M. G., Horn, H. A., McDonald, B. R., Stankey, R. J., ... Currie, C. R. (2017). Evolution and Ecology of Actinobacteria and Their Bioenergy Applications. Annu Rev Microbiol., 70(1), 235254.https://doi.org/10.1016/j.physbeh.2017.03.040

Li, Q., Chen, X., Jiang, Y., \& Jiang, C. (2015). Morphological Identification of Actinobacteria. In D. Dharumadurai (Ed.), Actinobacteria - Basics and Biotechnological Applications (p. 388). InterchOpen. https://doi.org/ 10.1016/j.colsurfa.2011.12.014

Louie, A., VanScoy, B. D., Brown, D. L., Kulawy, R. W., Heine, H. S., \& Drusano, G. L. (2012). Impact of spores on the comparative efficacies of five antibiotics for treatment of Bacillus anthracis in an in vitro hollow fiber pharmacodynamic model. Antimicrobial Agents and Chemotherapy, 56(3), 1229-1239. https:// doi.org/10.1128/AAC.01109-10

Matsumoto, A., \& Takahashi, Y. (2017). Endophytic actinomycetes: Promising source of novel bioactive compounds. Journal of Antibiotics, 70(5), 514-519. https://doi.org/10.1038/ja.2017.20

Messaoudi, O., Bendahou, M., Benamar, I., \& Abdelwouhid, D. (2015). Asian Pacific Journal of Tropical Biomedicine by new strain of actinomycete isolated from sebkha of Kenadsa , Algeria. Asian Pacific Journal of Tropical Biomedicine, 5(6), 438445. https://doi.org/10.1016/j.apjtb.2015.04.002

Mhondoro, M., Ndlovu, N., Bangure, D., Juru, T., Gombe, N. T., Shambira, G., ... Tshimanga, M. (2019). Trends in antimicrobial resistance of bacterial pathogens in Harare, Zimbabwe, 2012-2017: A secondary dataset analysis. BMC Infectious Diseases, 19(1), 1-9. https:/ /doi.org/10.1186/s12879-019-4295-6

Mohseni, M., Norouzi, H., Hamedi, J., \& Roohi, A. (2013). Screening of antibacterial producing actinomycetes from sediments of the caspian sea. International Journal of Molecular and Cellular Medicine, 2(2), 6471. Retrieved from http://www.pubmedcentral.nih.gov/ articlerender.fcgi?artid=3920526\&tool=pmcentrez\& rendertype $=$ abstract

Murugan, M., Srinivasan, M., Sivakumar, K., Sahu, M. K., \& Kannan, L. (2007). Characterization of an actinomycete isolated from the estuarine finfish, Mugil cephalus Lin. (1758) and its optimization for cellulase production. Journal of Scientific and Industrial Research, 66, 388-393.

Nett, M., Ikeda, H., \& Moore, B. S. (2009). Genomic basis for natural product biosynthetic diversity in the actinomycetes. Natural Product Reports, 26(11), 1362-1384. https://doi.org/10.1039/b817069j 
Owusu-Kwarteng, J., Wuni, A., Akabanda, F., TanoDebrah, K., \& Jespersen, L. (2017). Prevalence, virulence factor genes and antibiotic resistance of Bacillus cereus sensu lato isolated from dairy farms and traditional dairy products. BMC Microbiology, 17(1), 9-16. https://doi.org/10.1186/s12866-0170975-9

Priya, M., Anandaraj, B., \& Ganesan, T. (2015). Original Research Article Antimicrobial Activity of Estuarine Actinobacteria against Selected Human Pathogens, 4(9), 120-125.

Sahu, M. K., Sivakumar, K., Poorani, E., Thangaradjou, T., \& Kannan, L. (2007). Studies on L-asparaginase enzyme of actinomycetes isolated from estuarine fishes. Journal of Environmental Biology, 28(2), 465474.

Sathish, K. S., \& Kokati, V. B. R. (2012). In-vitro antimicrobial activity of marine actinobacteria against multidrug resistance Staphylococcus aureus. Asian Pacific Journal of Tropical Biomedicine, 2(10), 787-792. https:/ /doi.org/10.1016/S2221-1691(12)60230-5

Seipke, R. F., Kaltenpoth, M., \& Hutchings, M. I. (2012). Streptomyces as symbionts: An emerging and widespread theme? FEMS Microbiology Reviews, 36(4), 862-876. https://doi.org/10.1111/j.15746976.2011.00313.x

Sengupta, S., Pramanik, A., Ghosh, A., \& Bhattacharyya, M. (2015). Antimicrobial activities of actinomycetes isolated from unexplored regions of Sundarbans mangrove ecosystem. BMC Microbiology, 1-16. https://doi.org/10.1186/s12866-015-0495-4

Sharma, S. K., Chiang, L. Y., \& Hamblin, M. R. (2011). Photodynamic therapy with fullerenes in vivo: Reality or a dream? Nanomedicine, 6(10), 1813-1825. https:/ /doi.org/10.2217/nnm.11.144

Singh, V., Haque, S., Singh, H., Verma, J., Vibha, K., Singh, R., ... Tripathi, C. K. M. (2016). Isolation, screening, and identification of novel isolates of actinomycetes from India for antimicrobial applications. Frontiers in Microbiology, 7(DEC). https://doi.org/10.3389/ fmicb.2016.01921

Sivakumar, K., Sahu, M. K., Manivel, P. R., \& Kannan, L. (2006). Optimum conditions for L-glutaminase production by actinomycete strain isolated from estuarine fish, Chanos chanos (Forskal, 1775). Indian Journal of Experimental Biology, 44, 256-258.

Sperandio, F., Huang, Y.-Y., \& Hamblin, M. (2013). Antimicrobial Photodynamic Therapy to Kill Gram- negative Bacteria. Recent Patents on Anti-Infective Drug Discovery, 8(2), 108-120. https://doi.org/ $10.2174 / 1574891 \times 113089990012$

Subramani, R., \& Aalbersberg, W. (2012). Marine actinomycetes: An ongoing source of novel bioactive metabolites. Microbiological Research, 167(10), 571580.https://doi.org/10.1016/j.micres.2012.06.005

Taddei, A., Rodriguez, M. J., Marquez-Vilchez, E., \& Castelli, C. (2006). Isolation and identification of Streptomyces spp. from Venezuelan soils/ : Morphological and biochemical studies. I . Microbiological Research, 161, 222-231. https:// doi.org/10.1016/j.micres.2005.08.004

Umerska, A., Strandh, M., Cassisa, V., Matougui, N., Eveillard, M., \& Saulnier, P. (2018). Synergistic effect of combinations containing EDTA and the antimicrobial peptide AA230, an arenicin-3 derivative, on gram-negative bacteria. Biomolecules, 8(4). https:/ /doi.org/10.3390/biom8040122

Velho-Pereira, S., \& Kamat, N. (2011). Antimicrobial Screening of Actinobacteria using a Modified CrossStreak Method. Indian Journal of Phar, 73(2), 223228. https://doi.org/10.4103/0250-474x.91566

Ventola, L. C. (2015). Antibiotic Resistance Crisis. Pharmacy and Therapeutics, 40(4), 277-283. https:/ /doi.org/10.24911/ijmdc.51-1549060699

Walsh, C. T., \& Fischbach, M. A. (2010). Natural products version 2.0: Connecting genes to molecules. Journal of the American Chemical Society, 132(8), 24692493. https://doi.org/10.1021/ja909118a

Weber, T., Blin, K., Duddela, S., Krug, D., Kim, H. U., Bruccoleri, R., ... Medema, M. H. (2015). AntiSMASH 3.0-A comprehensive resource for the genome mining of biosynthetic gene clusters. Nucleic Acids Research, 43(W1), W237-W243. https://doi.org/ 10.1093/nar/gkv437

Zhang, J., Liu, G., Shang, N., Cheng, W., Chen, S., \& Li, P. (2009). Purification and partial amino acid sequence of pentocin 31-1, an anti-Listeria bacteriocin produced by Lactobacillus pentosus 31-1. Journal of Food Protection, 72(12), 2524-2529. https://doi.org/ 10.4315/0362-028X-72.12.2524

Zothanpuia, Passari, A. K., Chandra, P., Leo, V. V., Mishra, V. K., Kumar, B., \& Singh, B. P. (2017). Production of potent antimicrobial compounds from Streptomyces cyaneofuscatus associated with fresh water sediment. Frontiers in Microbiology, 8(JAN), 1-13. https://doi.org/10.3389/fmicb.2017.00068 